\title{
Catholic Innovation Through E-Rosary: Between Fascination and Disapproval
}

\author{
Qemal Affagnon \\ Internet Sans Frontières
}

The aim of this study is to show that digital technology now lies at the heart of the evangelizing mission of the Catholic Church. In view of the profound changes brought by the rise of digital communication technologies, the Vatican justifies this goal through a desire to reach believers in the remotest areas of the world. While at first glance this strategy gives the Catholic Church a modern image, the current research work brings it closer to the importance the Church attaches to global health interventions. Given the healthcare system failure in some African countries, this article which is based on Foucault's concerns about surveillance foresees a form of paternalism capable of fostering a mode of governance that subtly promotes the influence of individual behaviour.

Keywords: Catholicism, global health, beads, rosary, surveillance

\section{INTRODUCTION}

Between the Middle Ages and the modern age, the Catholic Church reinvented itself in a continuous process of reinvention. In many cases, this transformation was motivated by the ambitions of this worldrenowned institution. On the African continent, the Catholic institution thus initially took advantage of colonisation to set up its mission of evangelisation. For Bouron (2012), the functioning of Christian dispensaries has for a long time contributed to the realisation of colonial ambitions after the arrival of the first Catholic missions in Africa. Moreover, it appears in the national archives of Senegal that the Catholic missions have worked with dedication to spread French thought and influence through medical assistance during the colonial period. By promoting the spread of evangelisation during this period, the Catholic Church thus succeeded in supporting the work of African civilisation. Through their activities, these missions will introduce scientific medicine and the values underlying it to Africa.

\section{INTRODUCTORY NOTES}

Over time, the Catholic Church has thus managed to remain active on the continent, despite competition from the evangelical churches. Many of these evangelical churches have specialised in faith-based healing, an area of activity in which the Catholic Church is often distant. However, through healing processes that revolve around the power of God, evangelicals are increasingly gaining ground in Africa. For evangelicals, scientific medicine would not solve all problems. For this reason, the evangelical speech advocates the deliverance of society from the evil spirits that disturb it.

Despite the strong competition from the evangelical churches, the Catholic institution still has a large pool of followers. Aware of the number of its believers, the Catholic Church does not hesitate to invest in 
Africa in order to mark its presence. In this context, several States have accepted the collaboration of the Church. However, it is often required that this collaboration be part of a health policy defined by the States. Regardless of this framework, however, church activities can also compete with what the state provides. On this topic, many observers recognise the Catholic Church's beneficial actions in the health sector. On a continent where the health sector is confronted with a lack of investment by the authorities, the Church is sometimes the target of criticism. Among the criticisms is that the Church is sometimes blamed for offering only the Gospel in response to the problems of Africans. For many countries on the African continent, modern medicine is expensive and technical progress is accompanied by expenses that the States cannot always afford. This explains the fact that public authorities with limited means sometimes find it difficult to finance their medical institutions. It also shows that, despite the increase in cases of diseases such as cancer and cardiovascular disease in developing countries since the $1970 \mathrm{~s}$, the fight against chronic diseases remained relatively marginal on the global health agenda (Weisz, Vignola Gagné, 2015).

This continues to be the case despite the fact that global health policies, including the recent global health paradigm, refute the notion that chronic diseases affect mainly rich countries. Specifically, the global health paradigm refers to the rise of new actors in the field of global health such as the Catholic Church (Atlani-Duault, Vidal, 2013; Brown, Cueto, Fee, 2006). Like some researchers who point to a favourable turning point in global health policies from the 2000s onwards (Reubi, Herrick, and Brown 2016; Whitmarsh, 2013), it should be recognised that in recent decades, the interest of faith-based providers in the health sector has increased in Africa. At a time when the Catholic landscape is undergoing potentially disruptive changes, we will try to understand how the church is trying to reinvent itself through the connected market in Africa.

\section{THE CHURCH AND THE TENTACLES OF TECHNO - POWER}

In order to modernise its image, the Vatican decided to create the eRosary Click to Pray in October 2019. It is a new type of rosary that combines the characteristics of both the traditional rosary and digital elements. The new object of piety was designed in partnership with the Taiwanese firm Acer. Certified IP67, this rosary which has the shape of a bracelet composed of 10 black agates, 10 hematites and a silver cross is equipped with a 15 milliampere battery. The term IP stands for Ingress Protection. It is a rating scale for determining the dust and water resistance of certain electronic devices. In fact, IP67 smartphones can be immersed in water up to 1 metre for up to 30 minutes.

It should also be added that the new Vatican Jewel also incorporates a Bluetooth 5.0 module. This modern-day rosary also works with an Android or iOS application. In addition, it works with a processor built into the cross which is connected to the bracelet. It can last up to four days on a charge and has a gyroscope. While it can indicate a constant direction, thanks to an axis around which it rotates, the gyroscope is also sensitive to sound vibrations. Therefore, it can be used to record an audio conversation. With the help of certain audio processing algorithms, it is possible to refine the recordings of a gyroscope in order to recognise individual words in a conversation.

Once activated from a smartphone, the eRosary offers several prayer options for the believer. For example, it is able to display the user's progress in meditation and records each completed rosary. In addition, the new creation requires less than three hours of connection for a full charge. For the Vatican, the eRosary is able to capitalize on the popularity of the traditional rosary. For the leaders of the Catholic Church, the traditional rosary would still be able to revive the faith of many of the believers who use it to recharge their batteries, to recollect themselves and to praise the Lord for his blessings.

With 60 images and 64 audio recordings, a third of which are free of charge, the new rosary aims to amplify the virtues of the rosary. For the Church, the marketing of the eRosary is part of a strategy to win back a lost generation of believers. Beyond this objective, the Vatican is also seeking to counter the offensive of evangelical currents which are very active in the digital world. Indeed, the Church seems to have very quickly become aware of the challenges it is now facing because of the presence of evangelists in Africa. The leaders of the Catholic Church have thus addressed this problem because in an interim report, 
made public on May 03, 1986, the Secretary for Christian Unity had submitted a number of proposals in reaction to the development of new religious phenomena.

Among the measures proposed by the Secretary for Christian Unity was the suggestion, among others, that the classical models of liturgy should be revised in order to enhance the value of prayer and worship. On this subject, Lesegrétain (1993) mentions that the Standing Committee of the Symposium of Episcopal Conferences of Africa and Madagascar attempted to provide answers at a meeting held in 1992. At that meeting, the Standing Committee of the Symposium of Episcopal Conferences of Africa and Madagascar drew up a list of challenges for the Catholic Church in response to the emergence of new religious phenomena. Starting from the premise of the economic collapse and social alienation of the continent, the Committee suggested that the churches should become more involved in the social debates on the African continent. However, in the face of the mixed results that these proposals have produced, Cakpo (2013) reports that Cardinal Crescenzio Sepe, Prefect of the Congregation for the Evangelisation of Peoples, declared in June 2004 that the Catholic Church should strengthen religious instruction. Meanwhile, Mercier (2011) noted that at that time the Catholic Church was losing market share to the neo-Protestants who were doing better than it was in Africa. ${ }^{1}$

However, it should be stressed that on the African continent, the Catholic Church has often been attacked for its association with the colonial system. Similarly, Borne and Falaize (2009) argue that from the 13th century onwards, European expansion was only possible through its association with religion.

According to Bouron (2012) this is how Lavigerie, who was archbishop of Algiers, integrated medical courses into the training of future missionaries in Africa. Although Archbishop Lavigerie recommends that his missionaries study African societies, Bouron (2012) notes that the observation of the local pharmacopoeia will lead to the construction of prejudices among priests. Under such conditions, Bouron (2012) specifies that the latter preferred to introduce a new religion and lay the foundations of a medicine hitherto unheard of in Africa. Continuing a tradition that goes back to the origins of Christianity, the Catholic Churches have thus succeeded in developing a medical activity linked to their missionary activities. Sixty years after African independence, the Catholic Church still plays an important role in the stability of several countries. In 2019, the Bishop of the Diocese of Goma in the Democratic Republic of Congo urged the Catholic believers to observe the rules of hygiene in their respective parishes. Through a letter addressed to the various parishes, the Catholic institution had decided to get involved in the fight against the Ebola virus disease. Faced with the coronavirus, the African episcopates also adopted strict measures to prevent the spread of the disease. While these decisions are in line with those taken by the local authorities, they confirm the will of the Catholic institution to restore its image while working for peace in African countries.

\section{A CHURCH IN LOSS OF INFLUENCE}

In Africa, the Catholic Church has always played an important role in reinforcing the values to which it is attached. In general, these values are rooted in the heart of the Gospel. These values also serve as a compass for the various religious structures in the conduct of their activities. Although it is a community of people united by faith, it is important to underline the existence of structures of power, power relationships, domination and conflicts of interest that are clearly visible within this religious institution.

In Benin, one recalls the decisive involvement of the Catholic Church in the success of the national conference of this West African country. This conference laid the foundations for the organisation of the very first presidential election in the history of this country in March 1991. Three decades after this important political event, it would seem that the influence of the Church is waning. In fact, the Catholic Church and its bishops who are the first masters in their dioceses are facing repeated governance scandals. Worldwide, millions of believers are increasingly shaken by abuses and cases of paedophilia, which are sometimes covered up by church authorities. In addition to the fact that these various events are causing the Church to lose its sacred character, they are promoting a slow erosion of the power of religious denominations. On social networks, it is possible to read criticisms of the Church that seem far removed 
from the concerns of believers. However, Foucault (1975) notes that this power results from processes of interaction between individuals.

In Africa, where the hyper presence of mobile telephony is real, the Church could thus strengthen its power through its connected object and position itself as an important player in the globalisation of the 21 st century. According to Foucault (1975) the arcane nature of this type of power, however, revolves around surveillance practices. For Foucault (1975) this type of power is undoubtedly linked to knowledge. This notion of knowledge, Foucault (1975) describes it as a source of power in biopolitics, a phenomenon linked to the constitution of human existence. This existence (Foucault, 1975) specifies that it refers to the life of individuals, their sexuality, their food, their health, their leisure which are sources of power.

In the same vein, the work of Pridmore and Wang (2019) attests to the fact that digital applications similar to eRosary and the research that has examined them mainly concern the field of health, meditation and physical well-being. Initially developed for the optimisation of sporting activities, eRosary-like applications are able to provide information on the health status or possible risks of illness of their users. Pridmore and Wang's research (2019) also notes the possibility for these applications, which observe the body's performance, to infer about twenty medical conditions. However, the Catholic Church is multiplying initiatives to finance its activities in regions where the population is growing strongly. By 2060, the largest number of Christians will be found in five African countries. These countries include Nigeria, the Democratic Republic of Congo, Tanzania, Uganda and Kenya. Thanks to their demographic weight, these countries will replace Russia, Germany and China on the list of the ten largest Christian populations.

In view of the ease with which African governments entrust the Catholic Churches with public responsibilities, one would think that the Holy See will remain a principal character in the African health landscape. However, this observation is combined with Foucault's (1975) concerns about surveillance. In fact, Foucault (1975) specifies that surveillance favours the emergence of power relations that operate on individuals and are immediately effective. In addition to the fact that they invest individuals, Foucault (1975) states that these power relations mark them, train them, supplicate them, force them to work and oblige them to perform ceremonies. Moreover, Foucault (1975) adds that this training activity is carried out through the various state institutions such as schools, administration, hospitals and prisons, which form a micro-penalty universe.

Under these conditions, Foucault (1975) explains that this knowledge-based power uses meticulous pedagogical techniques to contain any risk of disorder in society. In the light of these explanations, a technological innovation such as eRosary could be used for paternalistic purposes in Africa. In fact, through the use of smartphones, tablets and other digital devices, many digital applications allow their users to track and adjust their lifestyles, while monitoring their habits. These applications are, however, subject to criticism regarding the invasion of privacy in Africa at individual level. It should be stressed that while the use of digital technologies can stimulate better spiritual practices, these practices are subject to algorithmic control. Yet health systems in Africa are still subject to often hazardous management. In these societies that are sometimes characterised by health insecurity, Catholic dispensaries often appear as gifts in the eyes of the underprivileged populations of these countries. The Holy See's new invention could thus be a great success in Africa, as the continent could be home to more than four out of ten Christians by 2060. At the same time, real abuses are to be feared, as an algorithmic control could come into being. This type of control could thus take shape in situations where political leaders are unable to implement effective health policies. In addition, several studies have shown that self-monitoring applications can significantly influence the behaviour of their users. However, Foucault (1975) considers that the influences induced by these surveillance mechanisms serve as a springboard for the exercise of power.

Faced with the breakthrough of the evangelical movements, will the Catholic Church succeed in winning back its African followers with eRosary? Will the Vatican counter-offensive be able to distinguish itself by the new digital foundations of the Catholic faith? If the rosary can adorn itself with the most extraordinary virtues, it is important that the Church resist the blind pursuit of certain hidden interests at the expense of justice and human dignity. 


\section{CONCLUSION}

Among the activities that the Church carries out on the African continent, the health and well-being of its believers has always been a priority. The launch of the connected Rosary which has just been put on the market is no exception to this logic. Through its religious functions, this rosary is intended to attract new followers as the Church is facing an erosion of faith in some parts of the world. Faced with the lack of interest of new generations in prayer, the Church is thus betting on the connected rosary in order to find a solution to this problem. Beyond religious practices, the object that is on the market also serves as a tracker of activity. Indeed, it makes it possible to count the number of steps the user takes each day. In Africa, where the provision of health care is still one of the objectives of the Church, what will happen to the data collected through this rosary? In a context where the consumer society and globalisation encourage the rise of new markets, this question is now topical. In fact, on this continent, whose demographic weight serves as a springboard for the Catholic faith, the Church is progressing and prospering among the people. What does the future hold for these popular masses who are close to the morals preached by the Church and who are experiencing prodigiously accelerated social changes in a continent in transition? In these regions, it is true that believers still respect the authority of priests and nuns and continue to magnify their mission. In such conditions the Church still retains its prestige and enjoys a relative notoriety among these populations attentive to the message of Rome. Indeed, the Church still has a real hold on its African believers despite several disappointments. Despite this advantage to its credit, it is important that the Catholic institution considers the importance of individual liberties in its new social conquests.

\section{ACKNOWLEDGEMENT}

Translated \& edited by American Publishing Services (https://americanpublishingservices.com/).

\section{ENDNOTE}

1. See J. Mercier, "Divorce à l'européenne", L'Atlas des religions..., p. 52.

\section{REFERENCES}

Atlani-Duault, L., \& Vidal, L. (2013). Le moment de sante globale. Revue Tiers Monde, 215, 7-16. Borne, D., \& Falaize, B. (2009). Religions et colonisations. Afrique-Asie-Océanie-Amériques XVI eXXe siècle. Les Editions de l'atelier/Les Editions Ouvrières, p.335.

Bouron, J. (2013). Le paradigme médical en milieu catholique: Offre sanitaire missionnaire et demande de sante en Haute- volta. Histoire et Missions Chrétiennes, pp. 103-136

Brown, T.M., Et Cueto, M., \& Fee, E. (2006). The World Health Organization and the transition from International to global public health. America Journal of Public Health, 96(1), 62-72.

Cakpo, E. (n.d.). Le phénomène des Nouveaux Mouvements Religieux en Afrique. Disponible à l'adresse. Retrieved October 3, 2020, from https://www.editionsharmattan.fr/auteurs/article_pop.asp?no=27155\&no_artiste $=23911$

Foucault, M. (2004). Surveiller et punir. Gallimard, p.352.

Lesegrétain, C. (1993, May 12). Les défis aux Églises traditionnelles. Actualité Religieuse Dans le Monde, 15.

Mercier, J. (2011). L'identité protestante. Dans L'Atlas des Religions, Paris, Le Monde, pp. 54-55.

Reubi, D., Herrick, C., \& Brown, T. (2016). The politics of non-communicable diseases in the global South. Health \& Place, 39, 179-187.

Weisz, G., \& Vignola-Gagné E. (2015). The World Health Organization and the Globalization of chronic non-communicable disease. Population and Development Review, 41(3), 507-532.

Pridmore, J., \& Yijing W. (2018). Prompting Spiritual Practices through Christian Faith Applications: Self-Paternalism and the Surveillance of the Soul. disponible à l'adresse. Retrieved January 2, 
2020, from https://ojs.library.queensu.ca/index.php/surveillance-and-society/index Whitmarshl, L. (2013). The Ascetic subject of compliance. The turn to chronic diseases in global health. In J. Biehl \& A. Petryna (Dir.), When people come first: Critical Studies in Global Health (pp. 302-324). Princeton, Princeton University Press. 